\title{
Reflections from the retiring President of IUGS
}

It has been a very busy four years but, in these days of the decline of the geological surveys and many parts of the structures of the earth sciences, we have survived rather well. Our parent organisation, the International Council of Scientific Unions, and UNESCO, have supported us strongly, within the limits of their finances. In addition, many national groups, an expanding number in fact, have continued their support.

As the century closes, we are moving into a new world demography, and a world that many would say is overpopulated. The ultimate question facing all educated world citizens is, "can we support well, ten to twelve billion humans without destruction of our ultimate life support systems-truly sustainable development?". When one considers our systems for food, energy, materials, water, clean air, waste management, earth system science is an essential component. We have been too slow in accepting these new and urgent priorities.

During the highly successful 30th IGC in Beijing, most of these topies were considered. And, at the well-attended IUGS council meetings, various national groups called for new actions and better long-range planning of priorities. It has become clear that we need our journal Episodes as never before-Episodes which can be a place to exchange our ideas and freely discuss the needed actions. We are pleased that it is now almost certain that China will accept responsibility for our journal for the next few years.

I thank all the members of the Executive, and many other project leaders for their help, without which I could not have survived. Particularly thanks go to the members of the Bureau, Robin Brett (our new President of IUGS), our treasurer Michael Schmidt-Thomé, and our Norwegian secretariat with Hanne Refsdal. Without their support we would not have survived.

But, finally, I with to express what is perhaps my major concern at this moment. We are an International Union. As I sat through our council meetings, I observed that the audience was dominated by males from North America and Europe; I was aware that this council does not represent the world of the next century; perhaps appropriate for 1900 but not 2000 . We must move to correct this situation. We live on one planet from which are ultimately derive almost all our resources.

I wish the new president, bureau and executive well. We need new ideas, new priorities-evolve or die!

W S Fyfe

University of Westem Ontario, Canada

\section{The Hutchison Fund}

\author{
request for donations
}

Dr William W Hutchison, who was both President and Secretary General of IUGS, left a sum of money in his will to establish a fund to help support young geologists from developing countries to travel to International Geological Congresses. The IUGS Executive Committee decided that the IUGS would ask the international geological community to add to this fund, both because the cause is a very worthy one, and also to remember Bill Hutchison, a distinguished geologist, geological leader, and a warm, decent, fine man. Please think seriously of donating to the fund especially if you knew Hutch, but also because the developing world needs capable young geologists to help guide it into the future. Please send donations to:

\author{
Robin Brett \\ President, IUGS \\ US Geological Survey \\ 917 National Center \\ Reston, Virginia 22092, USA
}

We would prefer cheques in US dollars, to avoid the high bank charges for converting other currencies, but also welcome Visa and Mastercard (give account number and date of expiry). US residents are reminded that gifts of this nature are tax deductible. 